\title{
Prediction of the relevance of employees' competencies in context of organizations strategies change
}

\author{
Katarína Stachová ${ }^{[0000-0003-4761-2509]}$, Lucia Kohnová ${ }^{20000-0003-4787-3901]}$ and Natália \\ Vosátková $^{2}$ \\ ${ }^{1}$ Institut of management, University of Ss. Cyril and Methodius in Trnava, 91701 Trnava, Slo- \\ vakia \\ katarina.stachova@ucm.sk \\ ${ }^{2}$ Faculty of Management, Comenius University, Bratislava, Slovakia \\ lucia.kohnova@fm.uniba.sk; natalia.vostkova@fm.uniba.sk
}

\begin{abstract}
The Fourth Industrial Revolution is characterized by the onset of radical changes associated with the advent of new technologies that enable the dissemination and sharing of innovation much faster than ever before. The question arises, what will be the future of work, and how will the competencies of the employees and employers emerge in today's digital era? Study from the 2017 Manyika et al. claims that by 2030, 75 million to 375 million workers ( 3 to 14 percent of the global work force) will have to switch their actual job positions and their occupational cate-gories. In the sample of 50 Slovak companies, we have analyzed the expected focus of companies for the following 5-10 years. The most expected trend (48\% of com-panies) is greater focus on services. Further, one third of the analyzed companies expect to focus on expansion of business activities, creation of new additional services, expansion of company's operations and transition to digital way of providing services. More than 70 percent of analyzed companies see soft skills as important, followed by professional qualification and analytical skills.
\end{abstract}

Keywords: Human Resources Management, Competitiveness, Industry 4.0, Job Position.

\section{Theoretical background}

The Industrial Revolution was one of the most important developments for the society and has significantly impacted last 300 years in human history (Ližbetinová et al. 2017, Hudákova et al. 2019 Stacho, Stasiak, 2014, Levický et al. 2013). Humans finding ways on how to improve the living standards, along with the curiosity driven attempts to simplify everyday life have prepared an ideal surrounding for a new revolution. The result is humanity facing and living the digital revolution in its latest stage of so-called 4th Industrial revolution. An inevitable need for an advanced technology originating from the industrial revolutions is now empowered by this digital era, which 
represents an incremental part of our everyday life. Pathway to this phenomenon began to take place many years ago, and was essentially a global process, which is still shaping and changing the world in many ways (Pavlendová et al. 2020, Hitka et al. 2019, Stacho et al. 2015).

The steam engine is a perfect example of a technology that has saved work on a large scale. However, it has also brought insecurity into the world of work and employment as such, evolving over time into a growing fear of "technological unemployment" (Keynes 1930). Despite these concerns, technological innovation has always led to creation of new jobs, which in correlation have provided employment. Productivity growth derived from automation has been the most important driver of rising living standards. Over the last fifty years, technological change has led to a significant improvement in living conditions for world's population. One of the very first examples of observing transformation in everyday life is the invention of an automatic alarm clock, which was preceded by so-called "knocker uppers" - people working at the days of industrialized Britain, responsible for waking up the working class every day in order to help them start their working day in a factory on time. This role has lost its significance with the discovery of electricity and an automated, affordable, later massively produced alarm clock.

Nevertheless, fears of technological unemployment have proved to be an exaggerated response to the changing industrial environment. The obvious reason why this concern did not materialize can relate to Ricardo's famous chapter on machinery, which suggests that technological labor savings reduce the demand for undifferentiated labor and thus lead to technological unemployment (Ricardo 1819). However, as economists have long understood, an invention that replaces workers with machines will have effects on all product markets and related factors. Increasing efficiency in production, which directly reduces the unit price in direct proportion, which in turn will increase real wages and thus increase demand for products. Therefore, technological progress has two competitive effects on employment (Aghion, Howitt 1994). The first is the destructive effect - when technologies replace labor, which requires the subsequent redistribution of labor supply; and secondly, there is a capitalization effect, e.g. more companies are entering sectors where productivity is relatively high and leading employment in these sectors is expanding.

Although the capitalization effect has historically prevailed, our discovery of the importance of economizing the use of labor may skip the pace at which we find new uses for labor, as Keynes (1933) emphasized. The reason why human labor has won, is related to its ability to acquire new skills through learning (Goldin, Katz 2009). As informatization enters more cognitive realms, this will become increasingly challenging (Brynjolfsson, McAfee 2011). Recent empirical findings are therefore particularly worrying. For example, Beaudry et al. (2013) declare the decline in skills demand over the last decade, despite the growing number of workers with a university degree. They point to the fact that highly qualified workers have moved down the career or job ladder within their profession, taking over the jobs traditionally held by low-skilled workers. This has resulted in the suppression of low-skilled workers even lower in the professional rankings and, to some extent, even a complete expulsion from the labor force (Frey, Osborne 2013). 
Concerning historical facts and the preliminary changes that are taking place on a fast pace, it is reasonable to be expecting changes in work environment as a result. The OECD analysis (Share of jobs with risk of automation) from the 2016 estimated that around $14 \%$ of jobs across the OECD are at risk of automation, while another $32 \%$ are likely to represent significant changes. Pointing out that Western Slovakia is performing with it's almost $40 \%$ as the most vulnerable Country candidate with highest risk of a job automation with its densely located automobile production in West Slovakia. With comparison of the region of Bratislava (Slovakia) the difference is almost $10 \%$. The high disparity has been significant with regard to the potential risks of job automation in Czech Republic as well as in France. Another OECD hypothesis shows that almost $65 \%$ of our children will in the future occupy job positions and will work on activities that do not even exist yet. Throughout history, technological progress has significantly changed the composition of jobs and employment as such from agriculture and crafts, manufacturing, administration, services and management professions.

The question arises, what will be the future of work, and how will the competencies of the employees and employers emerge in today's digital era?

Regional changes unleased differences in accessibility of a good quality and required amount of open positions. Of course, this has a close correlation to the economic growth and gross domestic product rate as well as the diversity of the economy. The more diverse the economy the less impacted the country may be with the upcoming changes. Another study from the 2017 Manyika et al. claims that by 2030, 75 million to 375 million workers ( 3 to 14 percent of the global workforce) will have to switch their actual job positions and their occupational categories. Although there will be enough work to ensure full employment by 2030, a major transformation is also expected, which could correspond to or even exceed the extent of historical changes from agriculture and production.

More specifically workers will need to adapt, up to the extent to which their job belongs to the occupation with high risk of automation as well, because the machine learning will be able to cover most of the simple or more sophisticated repetitive or manual processes. Some of that adaptation will require higher educational attainment, or spending more time on activities that require social and emotional skills, creativity, high-level cognitive capabilities and other skills relatively hard to automate (Manyika et al. 2017). PWC supporting this statement with its research from the 2017 (Sizing the prize What's the real value of AI for your business and how can you capitalize?) discusses that $45 \%$ of total economic gains will come by 2030 from product enhancements. Artificial Intelligence stimulating consumer demand by its ability to create and drive greater product variety, with still more popular increased levels of personalization, attractiveness and affordability over time. In the short term, it could have the greatest impact on sectors such as financial services, where algorithms can lead to faster and more efficient analysis and evaluation. However, in the long term, the development of autonomous vehicles without a driver could mean that the greatest effects is to prevail in the transport sector. Automation will vary greatly depending on the industry. In contrast, while these technologies will not affect any sector, areas such as health which is to be affected on a relatively low scale due to greater dependence on social skills and human contact. AI and robots will play an important role in healthcare in the future, but 
they will work more with human doctors and nurses than replace them. The same would be true in the education sector based on PWC analysis (PWC et al. 2020).

The change is also begin to arise within the recruitment sector starting with the new generation of employees who are setting a new base for the future working population with regards to the new standard of skills expected from a candidate. The expectations and the hiring requirements, especially in a world of corporate companies, are indeed on a higher level, then what we have seen 10 years ago. Computer skills already longer belongs to one of the basic skills a candidate should dispose of. Ability to act independently, make fast decisions, continuously improve processes in order to automate and create workflows and tools that are contributing to higher effectiveness whilst handling well the time management and have high level of stress resistance.

Latest survey of the KPMG has disclosed a clear gulf between action and inertia when formulating a question about the future of HR. The employers as well are nowadays facing an array of historic challenges, deployed from speeding into a digital economy that is already transforming businesses and traditional human resources as well as the functions that serve them (Fullbrook 2019). Wolfgang Fischer, CEO of the Zurich Insurance Company, stated that people often lack the critical skills. He assumes as necessary for a candidate to be able to master set of required skills such as communication skills, presentation skills and the ability to build trust. Among the soft skills it is inevitable to master hard skills mostly IT knowledge and language skills, which are seen as an axiomatic requirement for today's candidates. This has been as well confirmed by BSCs (Business Service Centers which started to arrive to Slovakia at 1990 - most business service centers (BSCs) could be described as call centers) addressed by The Slovak Spectator. Most of them are currently filling various positions in IT, accounting and administration. English, German, but also French are most frequently required language skills among the foreign languages. According to Zuzana Kaňuchová, company spokesperson and Cluster Head Corporate Communication, among other positive qualities belong the IT affinity followed by a proactive approach, ownership and responsibility, customer orientation and strong interpersonal skills (Minarechová 2019).

Our analysis, based on the above-mentioned facts, focusses mainly on organizations operating in Slovakia, where we aimed to found out which directions the organizations plan to take in the horizon of 5-10 years. We focused strongly on diving deep in subject of which skills and knowledge parameters are gaining on importance on the analyzed organizations in the context of the expected changes brought by the Industrial Revolution 4.0

\section{Materials and methods}

The aim of the research was to analyze the importance of selected skills and knowledge of employees in the context of future orientation of companies. For the research purpose, we have analyzed 50 Slovak companies in February 2019. The sample consisted of 14 SMEs and 36 large companies. The data were collected through personal interview with representatives of the organizations and a questionnaire. We have analyzed two research questions. First research questions - "Which direction does your 
organization plan to take in the horizon of 5-10 years?" aimed to analyze what the expected changes in the businesses in the era of the Forth Industrial revolution are. Further we focused on the importance of skills and knowledge for the future, based on the question - "What skills and knowledge are gaining in importance in your organization in education and development - and do you expect a growing trend in them in the future?". For the purpose of data analysis, we have used statistical method of nonparametric Chisquare test to analyze the significance of differences between large companies and SMEs. The Chi-square test significance was tested at $\mathrm{p}<0,05$. To analyze the relationship among skills and expected business changes we have used correlation analysis.

\section{Results}

Table 1. Percentage comparison of expected business changes among large companies and SMEs.

\begin{tabular}{|c|c|c|c|c|}
\hline & sample & MSP & LARGE & $\begin{array}{c}\text { Chi- } \\
\text { square }\end{array}$ \\
\hline Expansion of production portfolio & $16 \%$ & $7 \%$ & $19 \%$ & 1.14 \\
\hline Change in production portfolio & $4 \%$ & $0 \%$ & $6 \%$ & 0.81 \\
\hline $\begin{array}{l}\text { Expansion of business activities, focus on } \\
\text { trade }\end{array}$ & $34 \%$ & $36 \%$ & $33 \%$ & 0.03 \\
\hline Greater focus on provided services & $48 \%$ & $36 \%$ & $53 \%$ & 1.18 \\
\hline Creation of new, additional services & $32 \%$ & $36 \%$ & $31 \%$ & 0.12 \\
\hline Planning major changes of business model & $14 \%$ & $21 \%$ & $11 \%$ & 0.89 \\
\hline Narrowing the focus of business activities & $0 \%$ & $0 \%$ & $0 \%$ & - \\
\hline Extending the scope & $36 \%$ & $36 \%$ & $36 \%$ & 0.00 \\
\hline $\begin{array}{l}\text { Switching to digital way of providing ser- } \\
\text { vices, goods }\end{array}$ & $34 \%$ & $21 \%$ & $39 \%$ & 1.7 \\
\hline Not planning any significant changes & $16 \%$ & $21 \%$ & $14 \%$ & 0.21 \\
\hline
\end{tabular}

In the sample of 50 Slovak companies, we have analyzed the expected focus of companies for the following 5-10 years. The most expected trend (48\% of companies) is greater focus on services. Further, one third of the analyzed companies expect to focus on expansion of business activities, creation of new additional services, expansion of company's operations and transition to digital way of providing services. None of the analyzed companies expect to be narrowing the focus of business activities. In the sample, we have further compared the plans between large companies and SMEs. While in percentual points we can observe some differences, the statistical analysis has not proven significance of these differences.

In the context of various business transformations, we have further analyzed the skills and knowledge that companies in our sample perceive as important in the company and expect to grow on importance in the future. More than 70 percent of analyzed companies see soft skills as important, followed by professional qualification and analytical skills. Digital competences and competences in the field of robotics and AI have been selected by less than a third of analyzed companies. 


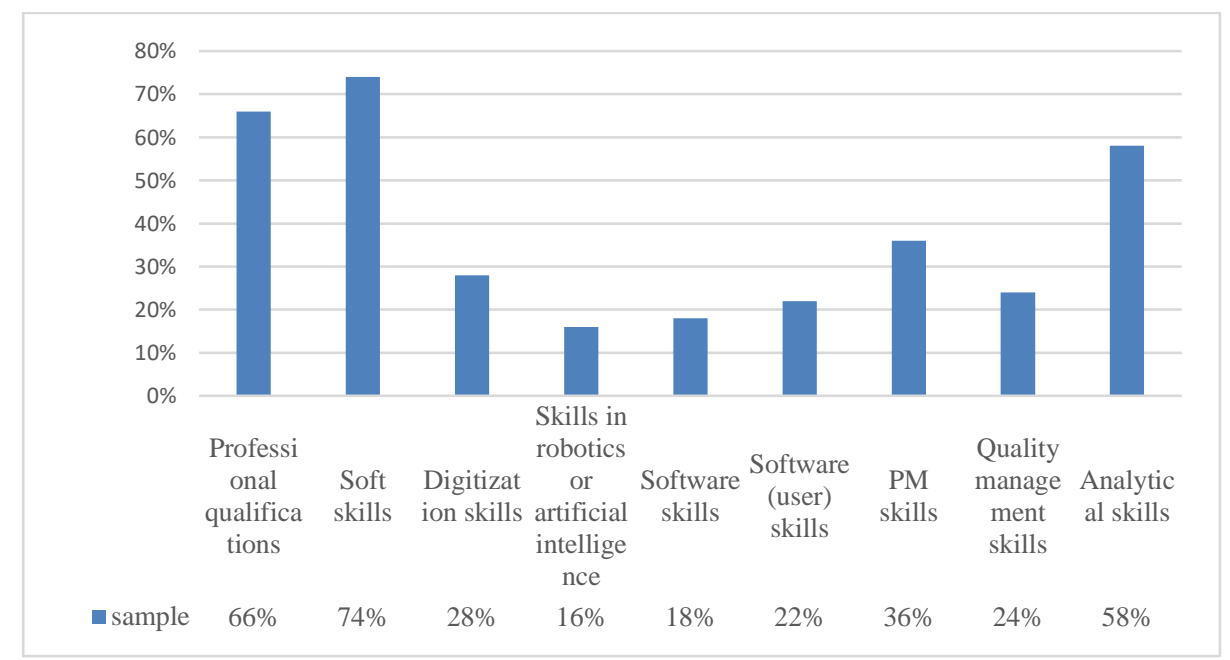

Fig. 1. Percentage comparison of perceived important skills of knowledge among analyzed companies $(\mathrm{N}=50)$

To identify the importance of selected skills, knowledge and competences in the context of future orientation of analyzed businesses we have conducted correlation analysis. When analyzing the most important skills and knowledge we observe that professional qualification has a positive correlation with expected business changes (plans) only in case of no significant changes expected (weak correlation - 0.2), on the other hand we observed medium negative correlation of -0.32 with plans of major business model changes. The most expected business change - greater focus on provided services we observed negative correlation with soft skills $(-0.16)$. This business focus however has a weak positive correlation with digital skills and skills in robotics and AI as well as software skills. Digital skills have a strong correlation with other expected business changes and focus (business focus selected by more than a third of analyzed companies) such creation of new additional services (strong correlation of 0,43 ) or transition to digital way of providing services (0.3).

Digital skills, as well as skills in robotics and AI and software skills (user skills) strongly correlate with changes in production portfolio. However, in our sample, only large companies have selected this option as a plan for next 5-10 years, thus these skills strongly correlate only in the context of large companies and their view on importance of these skills.

Table 2. Correlation matrix 1

\begin{tabular}{|c|c|c|c|c|}
\hline & $\begin{array}{c}\text { Expansion of } \\
\text { production } \\
\text { portfolio }\end{array}$ & $\begin{array}{c}\text { Change in } \\
\text { production } \\
\text { portfolio }\end{array}$ & $\begin{array}{c}\text { Expansion of bu- } \\
\text { siness activities, } \\
\text { focus on trade }\end{array}$ & $\begin{array}{c}\text { Greater focus } \\
\text { on provided } \\
\text { services }\end{array}$ \\
\hline $\begin{array}{c}\text { Professional qua- } \\
\text { lifications }\end{array}$ & $-0,15$ & $-0,07$ & 0,07 & $-0,07$ \\
\hline Soft skills & 0,01 & 0,12 & 0,04 & $-0,16$ \\
\hline
\end{tabular}




\begin{tabular}{|c|c|c|c|c|}
\hline Digitization skills & 0,09 & 0,33 & 0,02 & 0,11 \\
\hline $\begin{array}{c}\text { Skills in robotics } \\
\text { or artificial intelli- } \\
\text { gence }\end{array}$ & 0,11 & 0,47 & $-0,31$ & 0,13 \\
\hline Software skills & $-0,06$ & 0,17 & $-0,01$ & 0,18 \\
\hline $\begin{array}{c}\text { Software (user) } \\
\text { skills }\end{array}$ & 0,03 & 0,38 & 0,03 & 0,07 \\
\hline PM skills & 0,13 & 0,27 & $-0,01$ & 0,03 \\
\hline $\begin{array}{c}\text { Quality manage- } \\
\text { ment skills }\end{array}$ & 0,01 & 0,12 & $-0,01$ & $-0,07$ \\
\hline Analytical skills & 0,15 & 0,17 & 0,01 & 0,17 \\
\hline
\end{tabular}

Table 3. Correlation matrix 2.

\begin{tabular}{|c|c|c|c|c|c|}
\hline & $\begin{array}{c}\text { Creation } \\
\text { of new, } \\
\text { additional } \\
\text { services }\end{array}$ & $\begin{array}{c}\text { Planning } \\
\text { major chan- } \\
\text { ges of busi- } \\
\text { ness model }\end{array}$ & $\begin{array}{c}\text { Exten- } \\
\text { ding } \\
\text { the } \\
\text { scope }\end{array}$ & $\begin{array}{c}\text { Switching to } \\
\text { digital way of } \\
\text { providing ser- } \\
\text { vices, goods }\end{array}$ & $\begin{array}{c}\text { Not plan- } \\
\text { ning any } \\
\text { significant } \\
\text { changes }\end{array}$ \\
\hline $\begin{array}{c}\text { Professional qualifi- } \\
\text { cations }\end{array}$ & $-0,05$ & $-0,32$ & $-0,17$ & $-0,11$ & 0,20 \\
\hline Soft skills & $-0,08$ & $-0,02$ & 0,06 & 0,04 & 0,13 \\
\hline Digitization skills & 0,43 & 0,26 & $-0,10$ & 0,30 & $-0,27$ \\
\hline $\begin{array}{c}\text { Skills in robotics or } \\
\text { artificial intelli- } \\
\text { gence }\end{array}$ & 0,05 & 0,30 & 0,24 & 0,03 & $-0,04$ \\
\hline Software skills & $-0,10$ & 0,11 & 0,19 & $-0,12$ & $-0,06$ \\
\hline $\begin{array}{c}\text { Software (user) } \\
\text { skills }\end{array}$ & 0,05 & 0,20 & 0,21 & $-0,08$ & $-0,10$ \\
\hline PM skills & $-0,16$ & 0,06 & $-0,13$ & $-0,01$ & 0,24 \\
\hline Quality manage- \\
ment skills
\end{tabular}

To understand the importance of soft skills for companies, however its low correlation with expected business changes we have further looked at the dependence of this variable on the size of a company. The negative correlation of soft skills with the size of a company explains, that with the increasing size of a company the perceived importance of soft skills decreases (correlation -0,28). On the other hand, skills in robotics and AI correlate with the size (correlation of 0,25), being more important for larger companies than SMEs, similarly with skills in PM (correlation of 0,21) and skills in quality management (correlation of 0,2 ). 
Table 4. Correlation matrix - skills and company size

\begin{tabular}{|c|c|}
\hline & Correlation with company size \\
\hline Professional qualifications & 0,14 \\
\hline Soft skills & $-0,28$ \\
\hline Digitization skills & 0,12 \\
\hline Skills in robotics or artificial intelligence & 0,25 \\
\hline Software skills & 0 \\
\hline Software (user) skills & $-0,07$ \\
\hline PM skills & 0,21 \\
\hline Quality management skills & 0,2 \\
\hline Analytical skills & 0,09 \\
\hline
\end{tabular}

\section{Discussion and conclusion}

Discussions about the future of work are indeed in place. With the raise of technological opportunities and flexibility of both processes and employees we are facing a completely new concept which is about to be established all around the globe. In fact, we believe the establishment process has already started some years ago. This statement is based on the available variety of international researches, which are compared with the above results of questionnaire, which has taken place in 2020 on the sample of 50 Slovak companies and SMEs. Inevitable changes are to be seen along with the technological evolution in the manufacturing sector as well as within the service provider among all sizes of companies and employers. Significantly above the other options from the available statements on the given question "Which direction does your organization plan to take in the horizon of 5-10 years?" has proven to be an option placing stronger focus on the services and its providing. With result of $48 \%$ with no proven significant difference concerning the size of the company.

The innovative thinking about the big shifts that impact the industries are well to be seen in changes that are challenging the traditional logic and economics of the industries. One of such examples are Airbnb and Uber. Two companies that created a major shift in how we perceive and consume services. From the traditional industry has evolved a completely new model of behavior and ownership of these companies. Both based on the online platform providing a service from previously never to be taught possible, both businesses have transformed and opened up new competitive landscapes. Uber connecting taxi drivers with customers on a user friendly and convenient way, which is transparent for the customer and gives choices in order to satisfy individual needs. By providing this type of platform the company has proven that it is possible and today almost inevitable to redefine industries in terms of barriers to and competitive advantages, which as a result has contributed to changes among established organizations within particular industries. More than that the company enabled its platform to work independently and at the same time synchronized in many countries, enabling a customer to make user experience even more extended by supporting the app to work well even in the country one is visiting only for a holiday, without a need to search for another transportation options. The same model has been used and proven to work well for Airbnb founded in 2008, which today has more rooms than InterContinental Hotels 
or Hilton Worldwide with its concept not involving owning or physical asset management. Ensuring the low risk for the business and expansion is easily facilitated as no large investment are required in order to scale-up (Sörgärde and Sveningsson 2019).

Although companies have understood this need for services earlier, it is now confirmed by other researches, this direction is taking over the importance in order to keep pace with the global changes. These are being driven by many interacting trends including: changing demographics, urbanization, globalization, inequality, political uncertainty, and climate change.

Deloitte has in 2017 performed a research based on the discussions with large and small both public and private organizations, focusing on the top 150 of the FTSE350 highlighting a number of key issues businesses face while attempting to achieve 2030 Purpose. Trying to understand the purpose businesses stress out the most, when placing the strategies for the 2030, over half of businesses have direction of transformational statements, which provide an impetus for change (56\%). For example, Sage's purpose is "To energize the success of businesses and communities around the world through the imagination of our people and smart technology". This is an ever-moving target, which prompts the business to improve continually its products and services. Where the premise of the Transformation in this example is defined as purpose, which should provide an impetus for the business to change and to keep evolving (Deloitte 2017).

Closely related to the debates of the future perspectives and efforts of businesses are the skills that are changing along with the global as well as local enterprises. The way we work and perceive employment is shifting to more sustainable way. Lifelong learning became not only a trend but also a phenomenon companies and governments believe to keep the employees consistent and loyal. There is a clear connection to the benefits for businesses from such perspective (Work for a Brighter Future 2019).

Second question of our survey is unfolding the key skills businesses consider as key elements and assets of an employee, and they expect to grow on the importance in the future. Soft skills are considered by more than $70 \%$ of respondents as most important, followed by professional qualification and analytical skills. Less than a third of analyzed companies believe in importance of digital competences and competences in the field of robotics and AI. Importance of above-mentioned skills has proven to vary in context of the size of analyzed businesses, for which we have conducted correlation analysis. Therefore there is a proven dependence on the skill preference derived from the needs of a specific business with regards to the size of the business. The bigger the business the lower the importance of soft skills reveals to be. Exactly the other way around we uncovered a positive correlation in favor of the AI and skills related to robotics for the bigger companies whereas for the SMEs these did not reach such point of necessity. The same applies for the skills in Project Management and skills connected to Quality Management.

According to the research run by Pearson (world's learning company, consisting of experts in educational courseware and assessment, who provide teaching and learning services powered by technology) focused on reviewing the drivers of change and the interactions that are expected to shape industry structures and labor markets in 2030. Based on the data of O*NET (O*NET is the US Department of Labor's Occupational 
Information Network $\left(\mathrm{O}^{*} \mathrm{NET}\right)$, a free online database that contains hundreds of occupational definitions to help students, job seekers, businesses and workforce development professionals to understand today's world of work in the United States) interesting facts about the key tasks and skills that are gaining on importance were discovered. The findings show that the combination of interpersonal and cognitive skills has been an increasing preoccupation of policymakers in recent years. Findings for the US market place show strong emphasis on strong emphasis on interpersonal competencies, consistent with the literature on the increasing importance of social skills. In addition, a number of knowledge fields, such as English Language, Administration and Management, and Biology are associated strongly with occupations predicted to see rising demand - a reminder that the future workforce will have generic knowledge as well as skills requirements. In the UK, the findings support the importance of $21^{\text {st }}$ century skills too, though with an even stronger emphasis on cognitive competencies and learning strategies. System skills - Judgment and Decision-making, Systems Analysis and Systems Evaluation - feature prominently (Bakhshi et al 2017).

The conclusion from the analysis of PWC claims businesses are in high demand and need for skills, in particular: problem-solving, adaptability, collaboration, leadership, creativity and innovation top the list, and their ownership by new or existing employees has become the biggest threat to the business (Workforce of the future 2018).

We believe that every field and industry however has specific needs and expectations from the workforce and from the key skills that they should obtain. Overall more emphasis seems to be in proving independent decisions and good common sense combined with soft skills, adaptability, problem solving, project management skills and special technical or programming skills, especially for larger companies (Blštáková et al 2019, Gažová 2017, Hitka 2015).

To fill in the gaps in population, which will be the active workforce in Slovakia by 2030, exists an opportunity in dual learning, which is already in place and the concept brings skilled and feasible employees to market as they gain practical experience along with studying. In order to fulfill expectations in the fast growing business environment, companies need to support and provide sources, which are going to serve the employees in a way they can keep growing professionally and intellectually (Lizbetinova et al 2016, Kucharčíková et al. 2015). Lifelong learning however is a task for the future and existing workforce, as with arise of innovations we need to adapt our skills and knowledge accordingly in order to be able function along with the evolving technologies. The assumption of GDP increase derived from the accelerated development and take-up of AI will require skilled employees, who indeed need to prove their capabilities for even more challenging work positions.

\section{Acknowledgment}

Abstract. The research, whose results were processed in this paper was supported by the grant APVV-17-0656 entitled Transformation of Organizational Management Paradigm in the Context of Industry 4.0 


\section{References}

1. Aghion, P. and Howitt, P. (1994). Growth and unemployment. The Review of Economic Studies, vol. 61, no. 3, pp. 477-494.

2. Bakhshi, H. - Downing, J. M. - Osborne, M. A. - Schneider, P.: (2017) The Future of Skills Employment in 2030. In Pearson.

3. Beaudry, P., Green, D.A. and Sand, B.M. (2013). The great reversal in thedemand for skill and cognitive tasks. Tech. Rep., NBER Working Paper No.18901, National Bureau of Economic Research.

4. Blštáková, J., Joniaková, Z., Skorková, Z., Némethová, I., Bednár, R. (2019) Causes and Implications of the Applications of the Individualisation Principle in Human Resources Management. In AD ALTA : journal of interdisciplinary research, vol. 9, no. 2, pp. 323-327

5. Brynjolfsson, E. and McAfee, A. (2011). Race against the machine: How thedigital revolution is accelerating innovation, driving productivity, and irreversibly transforming employment and the economy. Digital Frontier Press Lexington, MA

6. DELOITTE (2017) 2030 Purpose: Good business and a better future. [21.06.2020]. <https://www2.deloitte.com/content/dam/Deloitte/my/Documents/risk/my-risk-sdg122030-purpose-good-business-and-a-better-future.pdf>

7. Frey, C. B., Osborne, M. A.: (2013) The Future of Employment: How Susceptible are Jobs to Computerisation? [08.03.2020]. <https://www.oxfordmartin.ox.ac.uk/downloads/academic/The_Future_of_Employment.pdf $>$

8. Fullbrook, L.: (2019) The future of HR is now. [14.06.2020]. Dostupné na internete: <https://amcham.sk/publications/issues/2019-2-work-in-slovakia-good-idea/article/272979/the-future-of-hr-is-now >

9. Gazova, A., Papulova, Z., Papula, J. (2016) The Application of Concepts and Methods Based on Process Approach to Increase Business Process Efficiency, Procedia Economics and Finance, Vol. 39, pp. 197-205, https://doi.org/10.1016/S2212-5671(16)30284-2.

10. Goldin, C. and Katz, L.F. (2009).The race between education and technology. Harvard University Press.

11. Hitka M., Balazova, Z. (2015) Comparison of Motivation Level of Service Sector Employees in The Regions of Slovakia and Austria. 2ND Global Conference on Business, Economics, Management and Tourism, Edited by: Iacob, AI., Procedia Economics and Finance, 23, 348-355. DOI: 10.1016/S2212-5671(15)00393-7

12. Hitka, M., Kucharčíková, A., Štarchoň, P., Balážová, Z., Lukáč, M., Stacho, Z. (2019) Knowledge and Human Capital as Sustainable Competitive Advantage in Human Resource Management .Sustainability 11(18) https://doi.org/10.3390/su11184985

13. Hudakova, M., Urbancova, H., Vnouckova, L., (2019). Key Criteria and Competences Defining the Sustainability of Start-Up Teams and Projects in the Incubation and Acceleration Phase. Sustainability Volume: 11 Issue: 23

14. Keynes, J.M. (1933) Economic possibilities for our grandchildren (1930). Essays in persuasion, pp. 358-73.

15. Kucharčíková, A., Tokarčíková, E., Blašková, M.: (2015) Human Capital Management Aspect of the Human Capital Efficiency in University Education. Procedia - Social and Behavioral Sciences Volume 177, 22 April 2015, Pages 48-60. <http://www.sciencedirect.com/science/article/pii/S1877042815016869\#>

16. Levicky, M., Gurcik, L., Porhajas, V., Horvathova, J. 2013. Some aspects of time-demand in the beekeeping production process in Slovakia. Proceedings from VIII. International Conference on Applied Business Research (ICABR 2013), APR 22-26, 2013 East London: SOUTH AFRICA 
17. Ližbetinová, L., Hitka, M., Li, C., \& Caha, Z. (2017). Motivation of employees of transport and logistics companies in the Czech Republic and in a Selected Region of the PRC. MATEC Web of Conferences. https://doi.org/10.1051/matecconf/201713400032

18. Lizbetinova, L., Lorincova, S., Caha, Z. 2016. The Application of the Organizational Culture Assessment Instrument (OCAI) to Logistics Enterprises. Nase More 63(3), 170-176. DOI: $10.17818 / \mathrm{NM} / 2016 / \mathrm{SI} 17$

19. Manyika, J., Lund, S., Chui, M., Bughin, J., Woetzel, J., Batra, P., Ko, R. and Sanghvi, S., 2017. Jobs lost, jobs gained: Workforce transitions in a time of automation. McKinsey Global Institute, 150.

20. Minarechová, R.: What skills do BSC employees need?. In Amcham.sk. [on-line]. 2019. [Citované 14.06.2020]. <https://amcham.sk/publications/issues/2019-2-work-in-slovakiagood-idea/article/272981/what-skills-do-bsc-employees-need>

21. Pavlendova, G.; Sujanova, J.; Caganova, D.; Novakova, R. Smart Cities Concept for Historical Buildings. Mob. Netw. Appl. 2020, 25, doi:10.1007/s11036-020-01521-7.

22. PWC, a kol.: How will automation impact jobs?. In PwC. 2020. [21.06.2020]. Dostupné na internete: <https://www.pwc.co.uk/services/economics-policy/insights/the-impact-of-automation-on-jobs.html >

23. Ricardo, D. (1819). The principles of political economy and taxation. World Scientific.

24. Sörgärde, N. - Sveningsson, S.: Managing Change in Organizations. New York: SAGE Publications Limited, 2019. s. 55 - 56. ISBN 9781529700299

25. Stacho, Z., Gubiniova, K., Pajtinkova B. G. (2015) Selected components of pricing strategies of organizations and their perception by customers in Slovak Republic, The Economic Annals-XXI Journal No. 9-10

26. Stacho, Z., Stasiak, B. R. (2014) Approach of organisations operating in Slovakia to employee's performance evaluation In: Ekonomičnij časopis-XXI. 5-6, pp. 82-85

27. Urbancova, H., Richter, P., Kucirkova, L., Jarkovska, M. (2017) Employer branding in the agricultural sector: making a company attractive for the potential employees. AGRICULTURAL ECONOMICS-ZEMEDELSKA EKONOMIKA 63(5), pp. 217-227. DOI: $10.17221 / 338 / 2015$-AGRICECON

28. Work for a Brighter Future: Report of the Global Commission on the Future of Work. In Ilo.org. 2019. [23.06.2020]. <https://www.ilo.org/infostories/en-GB/Campaigns/futurework/global-commission\#more>

29. Workforce of the future - The competing forces shaping 2030. In PwC. [online]. 2018. [Citované 23.06.2020]. Dostupné na internete: $<$ https://www.pwc.com/gx/en/services/peopleorganisation/publications/workforce-of-the-future.html> 